\title{
Nerws, Notes and Queries
}

I I. HIRSGH, op. cit., p. 84.

12. HEGKE R, op. cit., p. I91.

13. Ibid., p. 306.

14. Niemeyer, F. von, $A$ Textbook of Practical Medicine (8th edn.), trans. by G. H. Humphreys and C. E. Hackley, revised edn., London, H. K. Lewis, 188I, Vol. II, p. 694.

15. HIRSGH, op. cit., p. IIo.

16. Hirsch, op. cit., p. 85 .

I 7. HEBERDEN, W., the younger, Observations on the Increase and Decrease of Different Diseases, London, 1801, p. 70.

I8. GREIGHTON, op. cit., p. 272.

19. Os le R, W., The Principles and Practice of Medicine, 6th edn., London, S. Appleton, I905, p. 367 .

20. Ste Lwa G ON, H. W., Treatise on Diseases of the Skin, 7 th edn., Philadelphia and London, W. B. Saunders, I9I5, p. Iogi.

21. Gerste R, A. G., What was the English Sweating Sickness?, Bull. Johns Hopk. Hosp. 1916, 27, 332-7.

22. Fairley, H., Relapsing fever, $A$ Textbook of the Practice of Medicine, $7^{\text {th }}$ edn., ed. by F. W. Price, Oxford University Press, 1946, p. 251.

23. HirsGH, op. cit., p. 87.

24. Carus, op. cit., p. 360 .

25. Greighton, op. cit., p. 241 .

26. Ibid., p. 246.

27. Ibid., p. 247.

28. Ibid., p. 25 I.

29. Вам т то , S. S., Toxins and fungi, Times Science Review, No. 45, autumn, 1962, p. 6.

30. Willan, R., On Cutaneous Diseases, London, J. Johnson, 1808, vol. I, pp. 499-500.

31. Galen, De Alimentorum Facultatibus, Bk. I, ch. 37, D. G. G. Kühn's edn., Leipzig, I825, Vol. VI, p. 55I.

32. 'I NQUIRER', What was the nature of the Sweating Sickness?, Edinb. med. surg. J., I808, 4, 464.

\section{WILLIAM HUNTER ON WILLIAM HARVEY*}

\section{'Harvey was a man of Infinite Talents, a Lover of the Sciences in General.'†}

William Hunter proclaimed his interest in William Harvey in several ways. He bought a well-known portrait and he acquired some of his books, which he read closely and admired. Recently there has come to light a manuscript of twenty-six pages, the first eighteen of which are in William Hunter's own hand, and the last eight in that of Dr. David Pitcairn of St. Bartholomew's Hospital, who made some notes for Hunter.

* Paper read to the Harveian Society of London at its meeting in Padua, June 1963.

$\dagger$ MS. note by one of his students written at a lecture given by William Hunter in 1775 . Now in Royal College of Surgeons, (42. c. 31, p. 87). Quoted by kind permission of the Librarian. 


\section{News, Notes and Queries}

When William Hunter died in 1783 , he left his large collections of books, manuscripts, paintings, coins, fossils and anatomical and pathological collections to the University of Glasgow, together with a sum of $£ 8,000$ to be used for their housing in a proper building, airy and well-lighted. This MS. was found in the Hunterian Library (not now housed in Hunter's original gift), among a collection of documents largely relating to his master, James Douglas ( $1675^{-1} 74^{2}$ ), anatomist, teacher and physician, for whom Hunter worked in $1741 / 42$ and whom he greatly revered. This collection, known as the Blackburn Cabinet, has been catalogued, the present MS. receiving the number $28 . .^{1}$

The document is headed thus, in Hunter's most legible hand-Historical Anecdotes of Dr. William Harvey by Wm. Hunter, collected from family papers, etc., communicated to me by Councillor Eliab Harvey of Lincoln's Inn-fields, from the College book, from his own writings, from writers, from the Records in St. Bartholomew's etc. (Fig. I opp. p. 286).

It is not dated, and the only internal evidence as to its date is inconclusive and confusing.

Eliab Harvey (1 758-1830), from whom Hunter obtained much of his information, was descended from that Eliab ( $1588-1661$ ), William Harvey's younger brother, who for so long looked after William's interests, as we known from Aubrey. ${ }^{2}$ Our Eliab was the second son of William Harvey of Rolls Park, Chigwell, Essex, which property he later inherited, and which passed, with the Harvey portraits on its walls, through his daughter, Louisa, to the family of Lloyd, the present owners. Eliab Harvey had a distinguished, though turbulent, naval career, being in command of the Fighting Téméraire, $9^{8}$ guns, at the Battle of Trafalgar: she was the second ship of the weather line, closely following the Victory, and she took a brilliant part in the engagement. Eliab Harvey later became very angry and abusive at the advancement of Lord Cochrane in what he considered to be his place, as a result of which he was courtmartialled and dismissed from the service. In the following year, 1810, he was reinstated and advanced to be vice-Admiral of the Blue, being knighted in 1815.

Eliab Harvey became M.P. for Maldon, Essex, in 1780 , when twenty-three years of age. Thus the use, by Hunter, of the prefix 'Councillor' probably indicates that Hunter wrote these notes after this date, and in any case not much before, in view of Eliab's youth.

Hunter's MS. highlights a number of points in the life of Harvey, and a few which indicate that even after three hundred years of study, his work and activities may still provide a few minor surprises.

We come across one of these in the first few lines of the MS., which read ' $H$ is father, Thomas Harvey of Folkestone in Kent, near Dover, was born I 549 and died June 12, 1623 aet 74. The date on his picture by Cornel. Janssen which is preserved among the family pictures at Mr. Harvey's of Chigwell in Essex is 1614 being then 64 years old.'

From this we see that Hunter knew of the Rolls Park portraits, and indeed he possibly saw the portraits, though he does not mention this. Secondly, and more interesting, is the attribution to Cornelius Janssen, ${ }^{*}$ for later in the document, as we shall see, Hunter also ascribes the Rolls Park portrait of William Harvey (now in America) to Janssen. Up to the present time there has been no knowledge of the painter of these portraits, but it is certainly not impossible that they were painted by Janssen.

* Cornelius Johnson was born in England, changing his name to Janssen van der Ceulen in 1643 , when he went to Holland. 


\section{Nerws, Notes and Queries}

The portraits were painted in the period $1614-1630$ : at the earlier date Janssen was twenty-one years old and the Dictionary of National Biography states that he was at work in London in 1618 , noticing also that he went in $16{ }_{3} 6$ to reside near Canterbury where he painted many local family portraits. These dates do not quite coincide, but they may be close enough to give weight to Hunter's statement.

Sir Geoffrey Keynes agrees that there is nothing to be said against this attribution, but he is doubtful if the Rolls Park ovals are of high enough quality,* and we have only Hunter's word for it. d'Arcy Power ${ }^{3}$ says that Janssen painted several portraits of Harvey, including the well-known version in the Royal College of Physicians, made later in life, though doubt has been thrown, too, upon this attribution. We do know, however, that Janssen was noted for his family portraits, and it is by no means unlikely that an ambitious family such as the Harveys would desire to be perpetuated by a rising young painter. We shall return to Janssen and the Harvey portraits later.

Hunter gives a few details of Harvey's life, such as his birthday, I April I578, which he describes as 'Esther Tuesday' i.e. Easter. He mentions that Harvey travelled abroad in 1599 and was 'created Doctor of Physic 1602 aet 24,' returning home in December I602. There is no mention of Padua or of his teachers there.

'Five of his brothers,' wrote Hunter 'made great fortunes in the Turkey Trade, and raised so many families. Eliab Harvey, his next brother, to whom the Doctor left the greatest part of his fortune, bought an estate in Essex where he founded the present Chigwell family, built the family vault where Dr. Harvey now lies and raised the monument to Dr. Harvey as it now is.'

Hunter then gives details of Harvey's will; he wrote 'His last will and testament, now before me consists of 4 folio pages the first wrote by his relation Heneage Finch (afterwards Lord Chancellor Nottingham) and the last three in his own handwriting.'

All this is well known, but several interesting topics arise; first, where did Hunter obtain this will 'now before him'? If he had an original copy, did he buy it, borrow it or beg it from the Prerogative Court? Had it been his own copy, it would, before now, have been noted in the Hunterian Library, but there is no evidence of this and a recent search has failed to reveal any clue in Glasgow. We must therefore assume that he borrowed an official copy for perusal, possibly with the aid of the family. That it was an original version is probable, as shown by the attempt to copy the signature. Though the 'Will' (for William) is not convincing, the 'Harvey' could have been an attempt to reproduce the original hand. (Fig. 2 opp. p. 286).

Of the other signatories, Heneage Finch 1621-82, was a well known lawyer, later to become first Earl of Nottingham and Lord Chancellor of England. He married Elizabeth Harvey, daughter of William's younger brother Daniel, and therefore, as Hunter says, was a relation to William Harvey. Edward Deering bore the same relationship, having married one of Eliab Harvey's daughters, and John Raby who witnessed the codicil to the will, was William Harvey's faithful servant, to whom Harvey bequeathed $£_{20}$ 'for his diligence in my service and sicknesse'.

The will itself has been published, ${ }^{4}$ and though Hunter has copied portions of it, we learn nothing new. One question comes to mind, which does not appear even to have been asked, or answered. It refers to the paragraphs in the will which say

and whereas I have lately purchased certain lands in Northamptonshire or thereabouts commonly known by the name of Oxon Grounds and formerly belonging to the Duke of

\footnotetext{
* Personal communication.
} 


\section{News, Notes and Queries}

Manchester. And certain other grounds in Leicestershire commonly called or known by the name of Baron Park and sometime heretofore belonging to Sir Henry Hastings, Knight, both which purchases were made in the name of several persons nominated and trusted by me ..,

with directions that the estates should be left in trust to these 'several persons' and after further instructions, 'in default ... then to Eliab Harvey', following an assignment of ro July 175 I. Eliab Harvey, William's brother and business manager, was the residual legatee of the whole estate. No reference has been found to these estates in Northamptonshire and Leicestershire in any of the lives of Harvey and one wonders why he bought them so late in life-he was then seventy-three-and who were the unnamed trustees to whose support the rents were apportioned. Finding the answer would provide a nice exercise in county archival research. Harvey was most generous to his relations in his will, remembering distant relatives such as 'the poor children of Amy Rigdon daughter of my lo(ving) uncle Mr. Tho. Halke', and a person called Will Fowkes-possibly a deformed or subnormal child-who was looked after by Harvey's niece Mary Pratt of Coombe near Croydon. So it may be that these lands were designed to provide an income for such purposes and that eventually their ownership passed to the family of Eliab Harvey.

We now come to an even more interesting part of the MS. On pages 9 and 10 is a list which Hunter headed, 'the pictures remaining of him are . . $\therefore$ ' 1 . In the Combination room Caius College Cambridge. In old age'. This is patently not a portrait of Harvey, and Sir Geoffrey Keynes ${ }^{5}$ describes it as an unknown subject. d'Arcy Power ${ }^{6}$ seems to accept it as a likeness of Harvey, but states, on authority of the Master, that it was given to Caius College in 1798 , by the Earl of Leicester. Hunter knew that it was there at least fifteen years before this date.

The second portrait which Hunter knew is described by him thus: 'In the College of Physicians, London. In old age.' This is the best known portrait of Harvey, and, if Hunter's earlier attribution is correct, it is the second which Janssen painted of his subject, though Keynes says that the attribution of this portrait to this artist is conjectural. Since Janssen left England for Holland in 1643 , and since the events of the previous two years were hardly conducive to portrait painting for a Royalist follower-Harvey had been in Scotland with the King in 1641, and was in Oxford for most of 1642 -it would seem, according to Hunter, that the portrait was painted not later than 1640 in Harvey's sixty-second year. This would hardly accord with the apparent age in the portrait, for Harvey appears here as a really elderly gentleman.*

Hunter's third picture is described as 'in the Royal Society, London'. This portrait was presented to the Royal Society by John Mapletoft, I63I-I 72 I, who was made a Fellow in $1675 / 76$. Keynes throws doubt on the authenticity of this portrait, considering it to have been a posthumous production, meant to represent Harvey, and painted at any time up to sixty years after his death. This portrait was engraved by $\mathrm{E}$. Scriven in 1803 , when it was attributed to Cornelius Janssen, but again there is no direct evidence for this. When one examines all the evidence with the proper degree of caution, it seems that the correct course is to maintain a very open mind about Cornelius Janssen as the painter of any Harveian portraits.

The fourth picture which Hunter lists appears merely as 'Oxford', and is perhaps the Bodleian Library portrait; this is plainly derived from the Royal College of Physicians' painting, and was given to the University by Humphrey Bartholomew of University College in I 735, as one of a set of eight doctors.

\footnotetext{
* Sir Geoffrey Keynes does not think that the R.C.P. portrait could possibly be by Janssen.
} 


\section{Nerws, Notes and Queries}

Fifth, Hunter mentions 'the portrait in Mr. Harvey's of Chigwell by Cornel. Johnson'. This is the Rolls Park portrait, now in America. We have already discussed the attribution to Janssen. It is interesting to know that Hunter knew of these portraits at Rolls Park, although their existence was forgotten until d'Arcy Power brought them to light again in 1929.7

Sixth is the portrait 'at Lord Winchilseas'. d'Arcy Power ${ }^{8}$ states that the portrait owned by J. P. Cobbold of Ipswich had formerly been owned by the Earl of Winchilsea, citing Dr. John Ogle's Harveian Oration for 1880. The Winchilsea family had a tenuous connection with Harvey since the Earls of Winchilsea were descended from Heneage Finch, cousin of the Earl of Nottingham (also Heneage Finch) who married Elizabeth Harvey. In any case, this portrait is unimportant, as by no stretch of the imagination can it be said to represent Harvey. Keynes ${ }^{9}$ and d'Arcy Power ${ }^{10}$ reproduce what seem to be variants of the same portrait. d'Arcy Power reproduced the Ipswich version, Keynes, a copy of this now in Caius College, Cambridge, in which the features and hands are markedly different.

The seventh portrait is of some interest, being described thus: '7. At Eliab Breton's at $4^{o}$ hill Enfield, by Sir Peter Lely. Supposed by the family to be best of him.'

This portrait is unknown, and Lely's name has not been connected with Harvey portraiture. Eliab Breton of Forty Hill, Enfield, died in 1785 . His Harvey portrait was sold in 1786 as 'a thing of little value,'11 and so this 'best portrait of him' remains a mystery. Could it have been the one which John Hunter is supposed to have acquired, but which was destroyed by fire in 1830 ?

'8. Dr. Meads afterwards in the possession of Robert Taylor, M.D.Lond. and now in mine.'

This is the well-known and attractive portrait attributed to William van Bemmel (1630-1 708) and now in the Hunterian Library at Glasgow. The head is very similar to that of the Royal College of Physicians painting, and Keynes believes it to be one of the most important sources of information about Harvey's appearance. We do not know when Richard Mead acquired the portrait, but there can be little doubt of its authenticity, for Mead was born but sixteen years after Harvey's death, and would, towards the end of the century, have known reliable witnesses to testify both to the portrait and to Harvey's appearance. The details of the Hunterian portrait are of interest. The book to which Harvey points has been identified as the work of Spigelius of which the 1645 edition contains a reprint of De Motu Cordis. The background has been shown by Wilson Steel, late of Glasgow University Library, to represent a view of Rome with Trajan's column and the church of S. Maria di Loreto. ${ }^{12}$ This is a reminder of Harvey's visit to Rome in $16{ }_{3} 6$, when he travelled to Austria in the train of the Earl of Arundel. Leaving the main party at Augsburg, Harvey travelled on his own through Innsbruck and the Brenner Pass to Venice where he met Lord Fielding, to execute a commission for the King. A letter from a member of the Embassy quoted by d'Arcy Power refers to 'honest little Harvey whom the Earl is sending to Italy about some pictures for His Majesty'; surely evidence that the connoisseur King trusted Harvey's artistic, as he did his professional, judgement.

A curious feature of the Hunterian portrait is the mention of Robert Taylor, M.D. The portrait was sold by auction with the Mead collections in March 1 754. According to Keynes, ${ }^{13}$ the British Museum sale catalogue records that the half-length portrait of Harvey was sold to Mr. Oram on behalf of Dr. Hunter. The price was 40 guineas. Hunter, however, categorically states that after Mead, it was in the possession of 


\section{News, Notes and Queries}

Robert Taylor, who lived from I710-62, and was a fellow of the Royal College of Physicians, Gulstonian lecturer, and Harveian orator in 1755.

The reference to Hunter has not been rediscovered in the Mead catalogues examined, and it seems possible that it was Taylor who won the portrait at auction in 1754, and Hunter who obtained it at Taylor's death in 1762 . It is confusing, however, that this date does not tally with the tentative date which we have given to the manuscript. On page 10 of his MS. Hunter originally wrote 'now in the possession of Robert Taylor', and at some later date, crossed out 'now' for 'afterwards', adding the exultant collector's cry 'and now in mine'. This should mean that the document was written prior to 1762 , and that Hunter, on acquiring the portrait, in his meticulous way corrected the entry. This, however, does not tally with the age of Eliab Harvey, who was but four years old in 1762 ; it may simply mean that the portrait was in the hands of Taylor's descendants, or executors, for twenty years before Hunter bought it.

The last portrait noted by Hunter is ' 9 . At Mr. Southwells'. This is now known as the King's Weston portrait, after the house near Bristol, which was built for Edward Southwell by Sir John Vanburgh about 1720 , and in which Southwell placed a large number of family portraits. The connection with the Harvey family came through his grandfather, Sir Robert Southwell, who married Elizabeth Deering (or Dering), Daniel Harvey's great grand-daughter.

Keynes considers this portrait of a gloomy, broken-down old man to be a poor posthumous representation of Harvey.

The list of portraits made out by Hunter is necessarily incomplete, but it includes all the most important works, and Hunter concluded his notes on the portraiture with a list of three prints: 'The prints of Harvey are:

I. In a doctors habit and chair, with a Bonnet in his right hand. It is in old age and as it is prefixed to his treatise $D e$ Generatione, it was probably done from what was thought his best picture.' This is quite interesting, for Keynes in his Bibliography of Harvey quotes a letter written by Jasper Needham to John Evelyn in 1649, which mentions a print made from the life, and intended to be added to his book, 'but that resolution altered: however I'll send you a proof with your book that you may bind it up with his book De Generatione' ${ }^{14}$ Keynes adds that both the letter and the book with the etching inserted are still in the Evelyn collection now housed at Christ Church, Oxford. It appears that Hunter knew this particular copy with this print in it. Keynes attributes the portrait very tentatively to Richard Gaywood, pupil of Hollar; the latter, with Harvey, accompanied the Arundel mission to Austria. The first edition of De Generatione, as published in $165 \mathrm{I}$, contains a curious allegorical frontispiece of Jove on a pedestal, which Keynes attributes also to Gaywood.

Hunter noted secondly the bust, engraved by Faithorne, affixed to the English translation of De Generatione, 1653 , of which, he says 'the character, and particularly the nose, is very different'; and thirdly 'Houbraken's (engraving) from Mead's picture'.

Hunter makes no mention of the bust which Mead had made from his portrait, by Peter Scheemaker (169I-I 770), and which Mead presented to the Royal College of Physicians in 1739 .

Of the bust by Edward Marshall (1598-1674) in Hempstead Church, Essex, Hunter remarks that 'Eliab Harvey his next brother . . . built the family vault where Dr. Harvey now lies . . . in a leaden coffin (of the shape of a man's body) the first of the row at the furthest end of the vault . . . and raised the monument to Dr. Harvey as 


\section{News, Notes and Queries}

it now is.' This is assumption, since Eliab built the Chapel and must have arranged the funeral. Keynes ${ }^{15}$ is of the opinion that the bust was done from the life.

On subsequent pages, Hunter lists Harvey's works 'which I have seen', eighteen names being noted and some bibliographical detail being given in many cases; for instance, of the Rotterdam $12^{\text {mo }}$ edition of De Motu Cordis, 1648, (Keynes 7), he remarks 'in the preface, Wood [i.e. Zachariah Sylvius, the editor] professes to have corrected and cleared the Text . . . and indeed he has made considerable alterations, considering that the author was alive. To be collated.'

We do not know how many Harveian books Hunter owned and collated; the Hunterian Library possesses eight editions of De Motu Cordis, two of the De Circulatione Sanguinis, two De Generatione.*

The remaining eight pages of the Hunter MS. consist of notes made by Dr. David Pitcairn (1749-1809), physician to St. Bartholomew's Hospital. They are a copy (partly in paraphrase) in mixed English and Latin, of all the entries referring to William Harvey in the Annals of the Royal College of Physicians. While these are of considerable interest, they are not so intimate nor so original as the notes which Hunter himself made.

This manuscript cannot be said to be of any great importance. It is, however, of much interest as a note made by one great doctor upon the life of another. Much that it concerns is well known, but it raises several queries and emphasises the fact that in the biography and iconography of such a man as Harvey, new facts, new questions and new concepts will continue to appear.

K. BRYN THOMAS

\section{ACKNOWLEDGEMENTS}

I acknowledge with gratitude the help of R. O. McKenna, Esq., Keeper of the Hunterian Books and MSS, University of Glasgow, who also granted permission to use the MS; L. M. Payne, Librarian to the Royal College of Physicians of London, for allowing me to compare the Annals of the College with Pitcairn's copy; and particularly Sir Geoffrey Keynes for his comments and encouragement.

\section{REFERE NCES}

I. Thом As, K. B., James Douglas of the Pouch and his Pupil William Hunter, London, Pitman Medical, I964.

2. Au b Rey, John, Brief Lives, ed. by Powell, London, I949, p. 230.

3. [D'Argy Power, ed.] Portraits of William Harvey, Proc. roy. Soc. Med., Hist. Section, I913, 6, 22.

4. Willis, R., The Works of William Harvey, M.D., London, Sydenham Society, I847, p. Ixxxix.

5. Keynes, G., The Portraiture of William Harvey, London Roy. Coll. Surgeons, I949, p. 3 I.

6. [D'Argy Power] op. cit., pl. VI.

7. - A memorial group of the Harvey family (Rolls Park) 1549-166I, illus., Ann. med. Hist., 1929, n.s. 1, 24 I-2.

8. - op. cit., (ref. 3), p. 40.

9. KEYNEs, G., op. cit., pl. 32 b.

10. [D'Arcy Power] op. cit., (ref. 3), pl. XVII.

* There is no evidence that any of these volumes belonged to William Hunter. 


\section{Nerws, Notes and Queries}

II. Robinson, W., History of Enfield, 2 vols., London, 1823.

12. Steel, W., Portraits of William Harvey, Brit. med. J., 1945, i, 758.

13. KeYNES, G., op. cit., p. 33 .

14. Keynes, G., A Bibliography of the Writings of Dr. William Harvey, London, Cambridge Univ. Press, 1953, p. 48.

15. KeYNes, G., op. cit., (ref. 5), p. 2 I.

\section{FIFTEENTH-CENTURY WOOD-GARVINGS IN ST. MARY'S GHURGH, BURY ST. EDMUNDS}

THE church of St. Mary, Bury St. Edmunds, Suffolk, was first constructed about I I 10-20 by Godfrey the sacrist. ${ }^{1}$ It was dedicated in 1142 by John, Bishop of Rochester, and the Gesta says that it was completed, with its tower, under Anselm. About 1425-30 it was much reconstructed and was then adorned with some of the finest woodwork to have survived the vandalism of Cromwell. As Whittingham says: 'On the richly-carved nave roof whose $\mathrm{E}$. truss is painted, hammer-beams with angels in a procession alternate with arch-braced trusses formed with a concealed hammerbeam. There are saints on the wall-posts. ... The panelled wagon roof of the rather earlier chancel has figures carved in the cusps, while its cornice is painted with angels carrying the Te Deum.'

Mary Tudor, Queen of France, buried in the abbey in 1533, now lies in the sanctuary and Queen Victoria erected an excellent window to her.

In spite of the magnificence of the wood-carvings, almost all of which are very well preserved, they had never been closely studied until the spring of 1964 , when Mr. Hallam Ashley made a photographic record of a large number of them. That this was possible is due to the enthusiastic co-operation of Canon R. G. R. Godfrey, the present incumbent.

One of the most interesting features about these wood-carvings is that a number of them appear to have some relationship to disease or medicine-in view of their ambiguity it would be injudicious to express it more strongly. Even those that have no direct medical link may perhaps have been indirectly influenced by the proximity of several hospitals and much sickness. Bury St. Edmunds had long been an important medieval centre for infirmaries. ${ }^{2}$ It catered not only for the medical needs of its own monastic and secular population but also for the vast numbers of pilgrims who visited the shrine of the martyred king and those, too, who thronged through the town on their way to the even holier shrine of Our Lady of Walsingham in Norfolk.

The six carvings illustrated here barely hint at the standard and richness to be found in the whole series. As far as their subjects are concerned little need be said about them.

Fig. I shows a doctor with his uroscopy flask. In the church the position of the figure is such that the flask is tilted forwards as though debouching its contents over 286 